\title{
Identification, abundance, and diversity of mosquitoes in Akure South Local Government Area, Ondo State, Nigeria
}

\author{
Olajide Joseph Afolabi", Joseph Onaolapo Akinneye and Aminat M. A. Igiekhume
}

\begin{abstract}
Background: Mosquitoes are known to be notorious for their ability to constitute a nuisance as well as transmit disease-causing organisms (pathogens) to hosts. This study was aimed to determine the species distribution, abundance, and diversity of mosquitoes in Akure South Local Government Area, Ondo State, Nigeria.

Results: A total number of 100 sites (20 sites from each location) were randomly sampled in the five locations (Alagbaka, FUTA, Oja-Oba, Ondo road, and Seebi). These larvae were identified to species level using $\times 20$ magnification of a dissecting microscope and identification keys. Thirteen species of mosquitoes including 5 Aedes species, 6 Culex species, and a species of Anopheles and Toxorhynchites belonging to four genera were recorded. The abundance of the four mosquito genera varied significantly $(p<0.05)$ with Culex having the highest abundance (2151) and Toxorhynchites having the lowest abundance (23). Also, the distribution and abundance of the mosquito species varied significantly $(p<0.05)$ with Culex andersoni being the most abundant species encountered (709) and Culex striatipes being the least abundant (8). The favorable physico-chemical parameters that favor breeding include $\mathrm{pH}$ range of $7.14-7.30$, temperature range of $27.3-29^{\circ} \mathrm{C}$, electrical conductivity range of 65.6-98.0 $\mathrm{\mu s}$, and dissolved oxygen range of 2.43-3.84 mg/l. Also, FUTA (1400) and Oja-Oba (994) had higher mosquito abundance than other locations (Alagbaka-124, Seebi-198, and Ondo road-224).
\end{abstract}

Conclusions: The persistent occurrence of Aedes, Culex, and Anopheles species pose a serious epidemiological concern to the inhabitants of Akure South Local Government Area. Therefore, public enlightenment on vector control is of paramount importance.

Keywords: Mosquito, Culex andersoni, Abundance, Diversity, Akure South

\section{Background}

Mosquitoes are the greatest enemies of humans because of the widespread suffering and death caused by the diseases transmitted. Mosquitoes also constitute a very important component in the determinants of insect-borne diseases of public health importance, especially in places where the availability of diverse water bodies support their breeding. The diversities of aquatic habitats for mosquito breeding frequently make them occur in adequate population to constitute biting nuisance or vectors of disease-causing organisms (Adebote, Abolude, Oniye, \& Wayas, 2008). An aquatic habitat for

\footnotetext{
* Correspondence: ojafolabi@futa.edu.ng

Department of Biology, Federal University of Technology Akure, Akure, Nigeria
}

oviposition is required by all mosquito species for larval and pupal development. McCrae (1984) reported that larval habitats water-type plays important roles in determining mosquito oviposition site selection, and hence, the productivity of such sites regarding adult mosquito emergence rates is critical factors determining the vectorial capacity of mosquitoes. Many species breed in both natural and artificial habitats such as concrete gutters, stagnant pools, abandoned plastics, abandoned tires, and even open unused drums (Afolabi, SimonOke, \& Osomo, 2013).

Mosquitoes are known to show preference to water with suitable $\mathrm{pH}$, optimum temperature, dissolved oxygen, concentration of ammonia, and nitrate (Afolabi et al., 2013). It has been suggested that the strong correlations found between certain physico-chemical 
parameters and larval abundance confirm the influence of these parameters on the distribution and abundance of mosquito larvae in their breeding habitats and also indicate the possibility of mosquito larval control through the manipulations of such parameters (Olayemi, Omalu, Famotele, Shegna, \& Idris, 2010). Malaria, Zika virus, filariasis, and yellow fever are diseases vectored by mosquitoes (Dawn, Kirk, Carl, \& Paul, 2001); these diseases cause high morbidity and mortality in human. Malaria is one of the most severe global public health problems worldwide, particularly in Africa, where Nigeria has the greatest number of malaria cases (World Health Organization, 2014). About half of the world's population is at risk of malaria; in 2015, there were roughly 212 million malaria cases and an estimated 429,000 malaria deaths (WHO, 2014). Nigeria suffers the world's greatest malaria burden, with approximately 51 million cases and 207,000 deaths reported annually while $97 \%$ of the total population is at risk of infection (WHO, 2014); yellow fever epidemics have also had devastating effects on human populations (Nasidi et al., 1989).

Ondo State is opportune to be among the states undergoing rapid urbanization of settlements in areas where only a scattered rural population existed formerly. This has actually resulted in some areas being densely populated. In such settings, organized sanitary facilities are usually poor; also, sewage disposal depends largely upon the initiative of the individual resident. Where water supply is available, there may be drains, soakage pits, peridomestic runoffs, and pools of standing water. Domestic conditions like these are ideal as breeding sites of some common mosquitoes such as Culex species and Aedes species. Therefore, the idea of this study was to identify the different species of mosquitoes found in Akure South Local Government Area of Ondo State, Nigeria, and to determine the distribution, abundance, and diversity of mosquitoes in the area. The study also aimed to evaluate the physico-chemical parameters of the aquatic habitat that determine the distribution of the mosquito larva species in the study area.

\section{Materials and methods}

\section{The study area}

A cross-sectional research was conducted in Akure South Local Government Area, Ondo State, Nigeria, within the period of January-December 2017. Akure South (Fig. 1) is one of the 18 local governments of Ondo State, Nigeria. The state lies between latitude $5^{\circ}$ $45^{\prime}$ and $8^{\circ} 15^{\prime}$ North, longitude $4^{\circ} 45^{\prime}$ and $6^{\circ}$ East. The state is bounded in the North-West by Ekiti State, WestCentral by Osun State, South-East by Ogun State, South-East by Delta State, and in the South by the Atlantic Ocean. The local government area has a land mass of $331 \mathrm{~km}^{2}$ and comprises of a total of 360,268 people at the 2006 census. The area thus encompasses various sectors of the work force: the government house, various manufacturing companies, educational institutions, small firms etc. The climate in the study area is tropical with two distinct seasons, the rainy season (April-October) and dry season (November-March) with slight variations from year to year. The annual rainfall varies from $1150 \mathrm{~mm}$ in the northern parts to $2000 \mathrm{~mm}$ in the southern area; the state generally enjoys luxuriant vegetation. The vegetation consists of coastal forest and mangrove swamp forest in the south, moist lowland forest, and the forest savannah in the north.

\section{Larval sample collection}

Larval sampling was done in twenty sampling point each of the five randomly selected locations in Akure South to generate stage-specific estimates of mosquito larval densities and diversity. These locations include Oja-Oba, Federal University of Technology Akure (FUTA), Ondo road, Alagbaka, and Seebi. Samples were taken from ditches, car tires, littered water containers, and buckets using standard dipping techniques with a plastic dipper from each habitat type; 2-10 dips were taken and the mosquito larvae collected and taken to the Public Health Laboratory of Biology Department, Federal University of Technology, Akure. The larvae were grouped according to instars as early (L1 and L2) and late (L3 and L4). The early instars were reared to late instars for more clarity, and the late instars were preserved in $70 \%$ ethanol and identified morphologically with $\times 20$ dissecting microscope and guided by morphological keys (Gillies \& DeMeillon, 1968; Hopkins, 1952). The relative abundance of mosquito and larval number per pool were calculated as below:

\section{Physico-chemical parameters of larvae habitats}

Relative abundance $=\frac{\text { Number of larvae collected per location }}{\text { Number of positive habitat per location }}$ Larva number per pool $=\frac{\text { Number of larvae collected per location }}{\text { Number of habitat examined per location }}$

Water samples from the various locations were collected and analyzed for physico-chemical properties such as $\mathrm{pH}$, temperature, dissolved oxygen, and conductivity. The $\mathrm{pH}$ and temperature were measured in situ using the HANNA $\mathrm{pH} /$ temperature meter (HANNA HI 991300), and the dissolved oxygen content and conductivity of the water samples were determined using a dissolved oxygen meter (HANNA HI 991300) and a conductivity meter (HANNA HI 991300), respectively, in the laboratory.

\section{Statistical analysis}

All data collected during the research were subjected to one-way analysis of variance (ANOVA) at $p<0.05$ and 


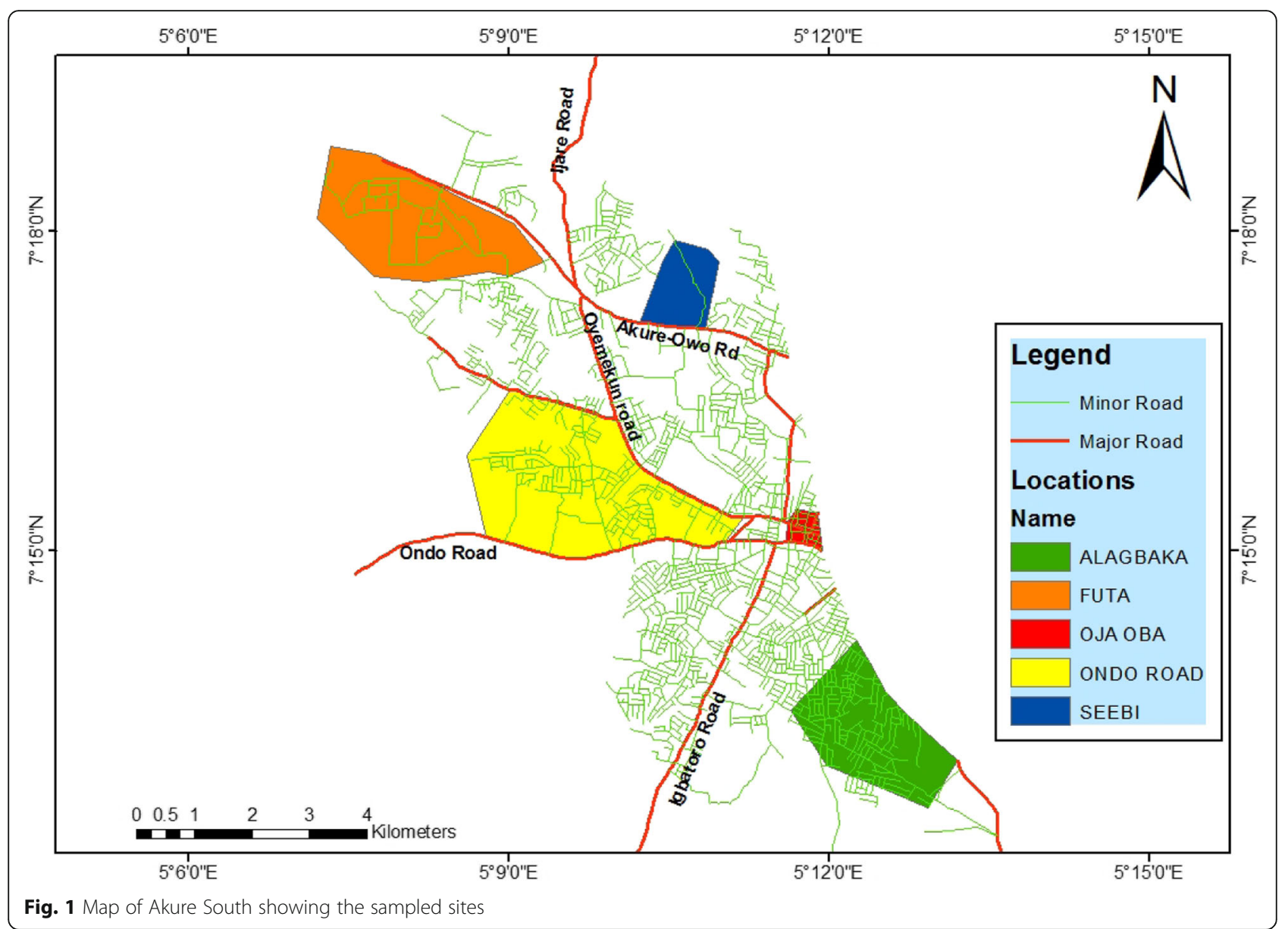

significant differences were observed. The means obtained were separated using the new Duncan multiple range test.

\section{Results}

Anthropogenic activities, physico-chemical parameters, and relative abundance of mosquitoes in Akure South Local Government Area

The anthropogenic activities of the study area as presented in Table 1 show that these activities vary significantly across the locations. Oja-Oba a predominant market in the study area is filled with carelessly disposed water-holding materials, puddles, gutters, and runoffs,

Table 1 Anthropogenic activities in the Akure South Local Government Area

\begin{tabular}{lll}
\hline S/N & Locations & Anthropogenic activities \\
\hline 1 & Oja-Oba & A market place \\
2 & FUTA & An educational institution \\
3 & Ondo road & A semi-urban settlement \\
4 & Alagbaka & An urban area \\
5 & Seebi & Semi-urban settlement \\
\hline
\end{tabular}

and FUTA which is predominantly academic environment consists of various classrooms, administrative buildings, student hostels, and small businesses. This location (FUTA) contains lots of peridomestic containers such as can, plastic, Styrofoam, bottles, gutters with stagnant water, puddles, and runoff which encourage massive populations of mosquito developing stages. Ondo road and Seebi on the other hand are considered semi-urban area comprising of small businesses along the road, supermarkets, and hotels with runoffs, gutters, and puddles. On the contrary, Alagbaka is an urban area that comprises of industrial buildings, government houses, hotels, event centers, restaurants, estate housing, and other various infrastructures. Alagbaka was observed to be neat environment with properly disposedoff wastes and minimum amount of stagnant water compared to other sampled locations. Nevertheless, the buildings in these locations held gutters, runoffs, buckets, and flower vases that serve as breeding sites for mosquitoes. The physico-chemical parameters of the breeding sites as presented in Table 2 reveal that temperature range of $27.3-29^{\circ} \mathrm{C}, \mathrm{pH}$ range of 7.14-7.3, dissolved oxygen range of $2.43-3.84 \mathrm{mg} / \mathrm{l}$, and 
Table 2 Relative abundance of mosquitoes in relation to physico-chemical parameters of the breeding sites in Akure South Local Government Area

\begin{tabular}{|c|c|c|c|c|c|c|c|c|c|}
\hline \multirow[t]{2}{*}{ Location } & \multicolumn{3}{|c|}{ Physico-chemical parameters } & \multirow{2}{*}{$\begin{array}{l}\text { Conductivity } \\
(\mu \mathrm{s})\end{array}$} & \multicolumn{2}{|c|}{ Number of pool } & \multirow{2}{*}{$\begin{array}{l}\text { Number } \\
\text { of larvae } \\
\text { collected }\end{array}$} & \multirow{2}{*}{$\begin{array}{l}\text { Relative } \\
\text { abundance }\end{array}$} & \multirow{2}{*}{$\begin{array}{l}\text { Larva } \\
\text { number } \\
\text { per poo }\end{array}$} \\
\hline & Temperature $\left({ }^{\circ} \mathrm{C}\right)$ & $\mathrm{pH}$ & Dissolved oxygen (mg/l) & & Examined & Positive (\%) & & & \\
\hline Oja-Oba & 28.0 & 7.14 & 3.58 & 67.0 & 20 & $19(95)$ & 994 & 52.32 & 49.7 \\
\hline FUTA & 28.6 & 7.16 & 3.84 & 68.6 & 20 & $18(90)$ & 1400 & 77.78 & 70.0 \\
\hline Ondo road & 27.3 & 7.30 & 3.76 & 98.0 & 20 & $13(65)$ & 224 & 32.00 & 11.2 \\
\hline Alagbaka & 28.0 & 7.16 & 2.43 & 82.0 & 20 & $8(40)$ & 124 & 15.50 & 6.2 \\
\hline Seebi & 29.0 & 7.18 & 3.27 & 65.6 & 20 & $15(75)$ & 198 & 39.60 & 9.9 \\
\hline Total & 140.9 & 35.94 & 16.88 & 381.2 & 100 & $73(73)$ & 2940 & 217.2 & 29.4 \\
\hline
\end{tabular}

conductivity range of 65.6-98 $\mu$ s favor mosquito breeding in Akure South Local Government Area, Ondo State. This is because mosquito breeding was confirmed in most of the habitats sampled during the study. For instance, the highest number of positive breeding sites $(n=19)$ was noted in Oja-Oba while the least number of positive breeding sites $(n=8)$ was observed in Alagbaka. Similarly, the highest number of larvae (1400), highest number of larva per pool (70), and highest relative abundance (77.78) were obtained in FUTA which corresponds with a relatively high temperature of $28.6^{\circ} \mathrm{C}$ and highest dissolved oxygen $(3.84 \mathrm{mg} / \mathrm{l})$. In contrary, the lowest number of larvae (124), lowest larva per pool (6.2), and least relative abundance (15.5) were observed in Alagbaka, an industrial area that is characterized with relatively low $\mathrm{pH}(7.16)$ and the lowest dissolved oxygen (2.43 mg/l).

\section{Composition and distribution of mosquitoes in Akure South Local Government Area}

A total number of 2940 mosquito larvae belonging to four genera were collected across the locations, and these larvae were distributed among 4 mosquito genera. The genera include Aedes, Anopheles, Culex, and Toxorhynchites. Of this total larvae population (2940), 714 larvae belong to the genus Aedes, 52 larvae belong to genus Anopheles, 2151 larvae were identified as genus Culex, and 23 larvae were identified as genus Toxorhynchites. Meanwhile, the highest number of Aedes
(358), Culex (628), and Toxorhynchites (15) were encountered in Oja-Oba and FUTA, respectively. The lowest number of Aedes genus (40) was observed in Alagbaka. It was noted that Anopheles genus was absent in Oja-Oba, Alagbaka, and Seebi while Toxorhynchites a predaceous genus was only found in Oja-Oba and FUTA. Anopheles, a notorious genus of malaria vector, was observed in FUTA and Ondo road (Table 3).

Further identification of the mosquito larvae into species as presented in Table 4 shows that the mosquitoes belong to 13 species which include 5 species of Aedes (Ae. aegypti, Ae. metallicus, Ae. dendrophilus, Ae. grahami, and Ae. vittatus), 1 species of Anopheles (An. gambiae), 6 species of Culex (Cx. andersoni, $C x$. tigripes, $C x$. quinquefasciatus, Cx. striatipes, $C x$. horridus, and $C x$. macfei), and 1 species of Toxorhynchites (Tx. brevipalpis). It was generally observed that Ae. aegypti (119), Cx. andersoni (141.8), and $C x$. tigripes (117) had the highest mean abundance in all the locations. Distribution of mosquito species across the locations shows that all the Aedes species with the exception of Ae. grahami were found in Oja-Oba. Meanwhile, Ae. aegypti and Ae. grahami were obtained in FUTA. All the Aedes species with the exception of Ae. dendrophilus were obtained in Ondo road while $A$ e. aegypti, yellow fever vector, and Ae. dendrophilus were found in Seebi. An. gambiae, the malaria vector, was only encountered in FUTA and Ondo road.

Table 3 Distribution of mosquito genera across sampled locations in Akure South Local Government Area, Nigeria

\begin{tabular}{|c|c|c|c|c|c|}
\hline \multirow[t]{2}{*}{ Location } & \multicolumn{4}{|c|}{ Mosquito genera } & \multirow[t]{2}{*}{ Total (\%) } \\
\hline & Aedes & Anopheles & Culex & Toxorhynchites & \\
\hline Oja-Oba & $358 \pm 0.35^{d}$ & $0 \pm 0.0^{a}$ & $628 \pm 1.03^{c}$ & $8 \pm 0.05^{b}$ & $994(33.8)$ \\
\hline FUTA & $171 \pm 0.17^{c}$ & $40 \pm 0.25^{b}$ & $1174 \pm 2.53^{d}$ & $15 \pm 0.19^{b}$ & $1400(47.6)$ \\
\hline Ondo road & $97 \pm 0.23^{b}$ & $12 \pm 0.11^{\mathrm{a}}$ & $115 \pm 1.55^{b}$ & $0 \pm 0.0^{\mathrm{a}}$ & $224(7.6)$ \\
\hline Alagbaka & $40 \pm 0.13^{a}$ & $0 \pm 0.0^{\mathrm{a}}$ & $84 \pm 0.73^{a}$ & $0 \pm 0.0^{a}$ & $124(4.2)$ \\
\hline Seebi & $48 \pm 0.21^{a}$ & $0 \pm 0.0^{\mathrm{a}}$ & $150 \pm 1.71^{b}$ & $0 \pm 0.0^{\mathrm{a}}$ & $198(6.7)$ \\
\hline Total & 714 & 52 & 2151 & 23 & $2940(100)$ \\
\hline
\end{tabular}

The significance increases from superscript a to $d$ 
Table 4 The distribution and abundance of mosquito species in Akure South Local Government

\begin{tabular}{|c|c|c|c|c|c|c|c|c|}
\hline Species & Oja-Oba & FUTA & Ondo road & Alagbaka & Seebi & Total & Mean \pm S.E. & Percentage \\
\hline Ae. aegypti & 303 & 160 & 52 & 40 & 40 & 595 & $119.0 \pm 51.24^{b}$ & 20.2 \\
\hline Ae. metallicus & 30 & 0 & 17 & 0 & 0 & 47 & $9.4 \pm 6.11^{\mathrm{a}}$ & 1.6 \\
\hline Ae. dendrophilus & 15 & 0 & 0 & 0 & 8 & 23 & $4.6 \pm 3.03^{\mathrm{a}}$ & 0.8 \\
\hline Ae. grahami & 0 & 11 & 10 & 0 & 0 & 21 & $4.2 \pm 2.58^{a}$ & 0.7 \\
\hline Ae. vittatus & 10 & 0 & 18 & 0 & 0 & 28 & $5.6 \pm 3.66^{a}$ & 0.9 \\
\hline An. gambiae & 0 & 40 & 12 & 0 & 0 & 52 & $10.4 \pm 7.76^{a}$ & 1.8 \\
\hline CX. andersoni & 260 & 302 & 68 & 29 & 50 & 709 & $141.8 \pm 57.55^{b}$ & 24.1 \\
\hline Cx. tigripes & 170 & 360 & 0 & 22 & 36 & 588 & 117. $\pm 67.50^{b}$ & 20.0 \\
\hline Cx. quinquefasciatus & 88 & 86 & 42 & 30 & 64 & 310 & $62.0 \pm 11.58^{\mathrm{ab}}$ & 10.5 \\
\hline CX. striatipes & 0 & 0 & 5 & 3 & 0 & 8 & $1.6 \pm 1.03^{\mathrm{a}}$ & 0.3 \\
\hline Cx. horridus & 52 & 206 & 0 & 0 & 0 & 258 & $51.6 \pm 39.89^{\mathrm{ab}}$ & 8.8 \\
\hline CX. macfei & 58 & 220 & 0 & 0 & 0 & 278 & $55.6 \pm 42.61^{\mathrm{ab}}$ & 9.5 \\
\hline Tx. brevipalpis & 8 & 15 & 0 & 0 & 0 & 23 & $4.6 \pm 3.03^{a}$ & 0.8 \\
\hline Total & 994 & 1400 & 224 & 124 & 198 & 2940 & $45.23 \pm 10.29$ & 100 \\
\hline
\end{tabular}

Means followed by the same superscript letters are not significantly different from each other $(p>0.05) p=0.015, \mathrm{df}=12$

Thirteen species of mosquitoes belonging to four genera were encountered during this study. The genera include Aedes, Culex, Anopheles, and Toxorhynchites. Five of the species belonged to the genus Aedes (Ae. aegypti, Ae. dendrophilus, Ae metallicus, Ae grahami, and Ae. vittatus) with Aedes aegypti having the highest distribution and abundance (595) while Aedes grahami had the least abundance (21) among the Aedes genera. Also, six species of Culex were identified (Cx. andersoni, $C x$. tigripes, Cx. quinquefasciatus, Cx. striatipes, Cx. horridus and $C x$. macfei) with Culex andersoni having the highest abundance (709) and Culex striatipes having the lowest abundance (8) among the Culex genera. The genera Anopheles and Toxorhynchites recorded just one species: Anopheles gambiae with an abundance of 52 and Toxorhynchites brevipalpis with an abundance of 23 , respectively. The distribution and abundance of the thirteen species varied significantly $(p<0.05)$ (Table 4$)$. It was also observed from the result presented in Table 4 that Aedes aegypti, Culex andersoni, and Culex quinquefasciatus were the most distributed species in the study area. This is because they were present in all locations sampled. In contrast, Ae. dendrophilus, Ae. grahami, Ae. vittatus, An. gambiae, Cx. striatipes, and Toxorhynchites brevipalpis were the least distributed as they were only found in two locations sampled. The species abundance of mosquitoes in the study area revealed that Culex andersoni (709) was the most abundant while Culex striatipes (8) was the least abundant encountered mosquito species. Meanwhile, in terms of species richness, Oja-Oba market is the richest as it contains 10 out of the 13 species encountered in the study area while the least is Alagbaka and Seebi with 5 species out of 13 species encountered. It should also be noted that $A n$. gambiae which is the main vector of malaria parasite was only found in FUTA (40) and Ondo road (12) with low abundance. Among the Culex species, it was only $C x$. andersoni and $C x$. quinquefasciatus that were found in all locations. Similarly, Toxorhynchites brevipalpis, a predaceous species, was only found in Oja-Oba $(n=8)$ and FUTA with low abundance $(n=15)$.

\section{Discussion}

Generally, it was observed from this study that locations such as FUTA and Oja-Oba that correspond with high relative abundance of mosquito larvae are areas with high anthropogenic activities such as school and market where there is high density of peridomestic containers such as plastics, cans, and Styrofoam. These peridomestic containers serve as habitats for mosquito breeding especially during the raining season. In contrary, locations such as Alagbaka and Seebi where low relative abundance was recorded are noted for good drainage system, good sanitation, and well-organized structures. These factors might contribute to low density of mosquito obtained in these areas. In addition, the significant difference of mosquito density across the locations may have been as a result of the disparity in social and economic activities within the locations that would encourage or discourage mosquito breeding. Hence, areas with high anthropogenic activities may have high population density of mosquitoes while areas with low anthropogenic activities may have low population density of mosquitoes.

It was further observed that physico-chemical parameters of the mosquito habitat determine mosquito oviposition and abundance. The physico-chemical parameters where optimal breeding were noted in Akure South 
Local Government Area include $\mathrm{pH}$ 7.16, temperature $28.6^{\circ} \mathrm{C}$, dissolved oxygen $3.84 \mathrm{mg} / \mathrm{l}$, and conductivity $68.6 \mu \mathrm{s}$. The optimal $\mathrm{pH}$ recorded in this study has also been reported by other authors (Adebote, Oniye, Ndams, \& Nache, 2006; Afolabi, Ndams, Mbah, \& Kogi, 2010; Okogun, Anosike, Okere, \& Nwoke, 2005). The authors reported that $\mathrm{pH}$ range of $6.8-7.2$ and 7.0-7.4 were suitable for the weakening of the mosquito egg shells for the emergence of its first instar larvae and that $\mathrm{pH}$ less than 5.0 and higher than 7.4 have fatal effects on survival of mosquito species. Optimal temperature suitable for breeding $\left(28.6^{\circ} \mathrm{C}\right)$ in Akure South Local Government Area also concurred with the reports of Clement (1992). The author reported that temperature and precipitation are keen factors which affect the abundance and distribution of mosquito in various habitats. A recent study conducted by Afolabi and Aladesanmi (2018) also shows that the optimal temperature that favored breeding in Akure North is $28^{\circ} \mathrm{C}$ while mosquito breeding is not likely to be found in temperature below $25^{\circ} \mathrm{C}$.

Of the 11 species of mosquito species observed in this study, $C x$. andersoni and Ae. aegypti had the highest abundance and distribution in all locations. This suggests that these two species are cosmopolitan and breed indiscriminately in all habitats. The dominance of Aedes and Culex mosquitoes had also been reported by Simon-Oke, Afolabi, and Olofintoye (2012) in Ekiti State, Nigeria. Likewise, Adeleke (2010) had earlier reported that Aedes mosquitoes prefer man-made larva habitats such as old tyres, clogged gutters, and animal pet bowls as breeding sites. These man-made habitats were abundant in the Akure South Local Government Area. In contrary, Anopheles gambiae was observed to be sparsely distributed and with relatively low abundance in FUTA and Ondo road. This low abundance of Anopheles might be due to their innate characteristics of endophagy (indoor feeding) and endophilic (indoor resting). Their association with human dwellings might suggest that Anopheles mosquitoes are selective breeders that breed in containers with clean water within and around human houses, for easy accessibility to host.

\section{Conclusions}

The four mosquito genera (Aedes, Anopheles, Culex, and Toxorhynchites) with the exception of Toxorhynchites encountered in Akure South Local Government Area are well-known vectors of parasites and help in transmission of diseases such as yellow fever, malaria, and filariasis. All these diseases are associated with high morbidity and mortality. Recently, resurgence of yellow fever has been reported in some part of Nigeria. This suggests that a sustainable public health campaign on vector management and control should be intensified in Nigeria.

\section{Abbreviations}

Ae.: Aedes; An.: Anopheles; Cx.: Culex; Tx.: Toxorhynchites; WHO: World Health Organization

\section{Acknowledgements}

The authors acknowledged the assistance of Miss Aladesanmi Omolola in collecting the larvae during the field work.

\section{Authors' contributions}

OJA and IAMA were involved in the collection of mosquito larvae from different habitats. Authors OJA and JOA participated in the design of the study and data analysis. OJA and IAMA gathered the literatures for the manuscript. The first draft of the manuscript was prepared by IAMA and edited by OJA and JOA. The final manuscript was read and approved by all the authors.

\section{Funding}

Not applicable

Availability of data and materials

All data generated or analyzed during this study are included in this published article.

Ethics approval and consent to participate

Not applicable

\section{Consent for publication}

Not applicable

\section{Competing interests}

The authors declare that they have no competing interests.

Received: 4 March 2019 Accepted: 28 May 2019

Published online: 11 June 2019

\section{References}

Adebote, D. A., Abolude, D. S., Oniye, S. J., \& Wayas, O. S. (2008). Studies on some physiochemical factors affecting the breeding and abundance of mosquitoes (Diptera: Culicidae) in Phytotelmata on Delonix regia (Leguminosa: Caesalpinoidea). Journal of Biological Sciences, 8(8), 1304-1309.

Adebote, D. A., Oniye, S. J., Ndams, I. S., \& Nache, K. M. (2006). The breeding of mosquitoes (Diptera: Culicidae) in peridomestic containers and implication in yellow fever transmission in villages around Zaria, Northern Nigeria. Journal of Entomology, 3(2), 180-188.

Adeleke, M. A. (2010). Population dynamics of indoor sampled mosquitoes and their implication in disease transmission in Abeokuta, South-Western Nigeria. Journal of Vector Borne Diseases, 47, 33-38.

Afolabi, O. J., \& Aladesanmi, C. O. (2018). Seasonal variation in distribution and abundance of mosquitoes (Diptera: Culidae) in Akure North Local Government Area, Ondo State, Nigeria. Uttar Pradesh Journal of Zoology, 38(4), 149-159.

Afolabi, O. J., Ndams, I. S., Mbah, C. E., \& Kogi, E. (2010). The effects of alteration of $\mathrm{pH}$ on the breeding characteristics of mosquitoes in phytotelmata in Ahmadu Bello University Zaria, Nigeria. International Journal of Biological Sciences, 5(1), 32-36.

Afolabi, O. J., Simon-Oke, I. A., \& Osomo, B. O. (2013). Distribution, abundance and diversity of mosquitoes in Akure, Ondo State, Nigeria. Journal of Parasitology \& Vector Biology, 5(10), 132-136.

Clement, A. N. (1992). Development, nutrition and reproduction of mosquitoes. In The biology of mosquitoes, (p. 536). London: Chapman and Hall.

Dawn, H. G., Kirk, A. S., Carl, O., \& Paul, B. (2001). Cooperative extension. College of Agriculture and Life Sciences, The University of Arizona, 26(2), 307-367.

Gillies, M. T., \& DeMeillon, B. (1968). The Anophelinae of the Africa South of the Sahara (Ethiopian Zoogeographical Region), (2nd ed., p. 54). Johannesburg: The South African Institute of Medical Resource.

Hopkins, G. H. E. (1952). Mosquitoes of Ethiopian region. Larval bionomics of mosquitoes and taxonomy of culicine larvae, (vol. 78, 2nd ed., pp. 307-318). London: Adlard and Sons Ltd.

McCrae, A. W. (1984). Oviposition by African malaria vector mosquitoes. II. Effects of site tone, water type and conspecific immature on target selection by 
freshwater Anopheles gambiae Giles sensu lato. Annals of Tropical Medicine \& Parasitology, 78(3), 301-318.

Nasidi, A., Monath, T. P., DeCock, K., Tomori, O., Cordellier, R., Olaleye, O. D., et al. (1989). Urban yellow fever epidemic in western Nigeria 1987. Transaction of Royal Society of Tropical Medicine \& Hygiene, 83(3), 401-406.

Okogun, G. R. A., Anosike, J. C., Okere, A. N., \& Nwoke, B. E. B. (2005). Ecology of mosquitoes of Midwestern Nigeria. Journal of Vector Borne Diseases, 42, 1-8. Olayemi, I. K., Omalu, I. C. J., Famotele, O. I., Shegna, S. P., \& Idris, B. (2010). Distribution of mosquito larvae in relation to physico-chemical characteristics of breeding habitats in Minna, north central, Nigeria. Reviews of Infectious Diseases, 1(1), 49-53.

Simon-Oke, I. A., Afolabi, O. J., \& Olofintoye, L. K. (2012). Species abundance and monthly distribution of adult mosquito vector in Ekiti State, Nigeria. FUTA Journal of Research in Science, 1, 83-88.

WHO (2014). World malaria report 2014. Geneva: World Health Organization.

\section{Publisher's Note}

Springer Nature remains neutral with regard to jurisdictional claims in published maps and institutional affiliations.

\section{Submit your manuscript to a SpringerOpen ${ }^{\odot}$ journal and benefit from:}

- Convenient online submission

- Rigorous peer review

- Open access: articles freely available online

- High visibility within the field

- Retaining the copyright to your article

Submit your next manuscript at $\boldsymbol{\wedge}$ springeropen.com 